\title{
A STUDY ON THE EPIDEMIOLOGY OF CHRONIC DACRYOCYSTITIS IN AN ECONOMICALLY-DEPRIVED POPULATION IN SOUTH INDIA
}

\author{
Soumya Sharat ${ }^{1}$, Nagaraja K. $S^{2}$ \\ ${ }^{1}$ Assistant Professor and Cornea Consultant, Department of Ophthalmology, Dr. B.R. Ambedkar Medical College Hospital. \\ ${ }^{2}$ Professor, Department of Ophthalmology, Dr. B.R. Ambedkar Medical College Hospital.
}

\section{ABSTRACT}

Dacryocystitis is infection of the lacrimal sac resulting from blockage of the nasolacrimal duct. This study was done to determine aetiopathogenesis of chronic dacryocystitis in an economically deprived population in South India. A total of 50 samples were obtained from the contents of the lacrimal sac in 50 patients with chronic dacryocystitis. These samples were cultured for aerobic and anaerobic bacteria and fungi with a routine microbiological technique. A total of 13 samples were obtained from 13 patients who underwent dacryocystectomy. The average age in the study was 52.5 years. Females predominated in the study (68\%). Of the cultures from the nasolacrimal sac, $84 \%$ were positive for bacteria. The majority of microorganisms in our study were gram-positive bacteria with a predominance of pneumococcus (40\%). Histopathological results of all 13 specimens showed non-granulomatous inflammation of the sac. Thus, every case of dacryocystitis has to be investigated to detect the predisposing and precipitating factor.

\section{KEYWORDS}

Dacryocystitis, Lacrimal, Dacryocystectomy, Bacteria.

HOW TO CITE THIS ARTICLE: Sharat S, Nagaraja KS. A study on the epidemiology of chronic dacryocystitis in an economicallydeprived population in South India. J. Evolution Med. Dent. Sci. 2016;5(70):5116-5117, DOI: 10.14260/jemds/2016/1160

\section{INTRODUCTION}

Dacryocystitis is one of the most common diseases of the eye that is encountered in daily routine ophthalmic practice. Dacryocystitis has a higher incidence among the people living in tropical countries with poor hygienic conditions. It occurs both in infants and adults, in men and women (having higher incidence of dacryocystitis presumed to be because of narrowness of nasolacrimal duct). It maybe inflammatory or noninflammatory, neoplastic, foreign bodies, dacryoliths, infective (bacterial, viral and fungal), noninfective (atonic), acute or chronic form. ${ }^{1}$ There may be an acute exacerbation of chronic dacryocystitis amounting to lacrimal abscess, which eventually may rupture and heal or form a chronic discharging lacrimal fistula. An infected lacrimal sac (chronic) is a constant source of infection and minor corneal abrasions are of daily occurrence, which go unnoticed and with a coexisting chronic dacryocystitis may lead to corneal ulceration and all its complications. This maybe to an extent of the loss of the eye due to panophthalmitis; hence, any case of corneal ulcer should always be tested for patency of the lacrimal sac. It can also cause scleral abscess, facial cellulitis, orbital cellulitis and cavernous sinus thrombosis. ${ }^{2}$

The source of infection maybe saprophytic, commensal organism from the conjunctival cul-de-sac or from the nasal cavity (which maybe nonpathogenic under normal environment of the lacrimal passage), but in an altered environment of sac may gain pathogenic characteristics leading on to dacryocystitis.

The cardinal symptoms of a case of dacryocystitis are watering/discharge through the affected eye. There may be stickiness of the eyelids during the waking hours, itching of

Financial or Other, Competing Interest: None.

Submission 02-06-2016, Peer Review 27-06-2016,

Acceptance 02-07-2016, Published 01-09-2016.

Corresponding Author:

Dr. Soumya Sharat

No. 25, Kamya,

$5^{\text {th }}$ Temple Road, 16 th Cross,

Malleswaram,

Bangalore-560003.

E-mail: soumya.sai@rediffmail.com

DOI: $10.14260 /$ jemds/2016/1160 eyelids, redness. There may be history of small opening at the medial canthus. Apart from the standard ocular examination, syringing of the lacrimal sac and microbiological study of the conjunctival cul-de-sac, lacrimal sac and the flora of the nasal cavity should be done to know, which of the organisms are affecting the lacrimal sac and also to know whether they are bacterial, fungal or viral in origin. ${ }^{2}$ All case of chronic dacryocystitis should be subjected to thorough rhinological examination to detect any nasal or paranasal pathology contributing to the disease or a contraindication to the nasal drainage procedure.

This study was done to determine incidence of the pathogens causing chronic dacryocystitis and analyse histopathological picture of chronic dacryocystitis in patients who are undergoing dacryocystectomy.

\section{MATERIALS AND METHODS}

The study comprises of 50 cases of chronic dacryocystitis including all age groups in both sexes. The patients were selected based on clinical history including distribution factors like age, sex, occupation and socioeconomic status of patient, nature and duration of symptoms and also patients detected during routine local investigative procedure for intraocular surgeries and corneal ulcer patients. All patients who underwent dacryocystorhinostomy were excluded as histopathological study could not be conducted in them.

Regurgitated material from the lacrimal sac was collected first by applying pressure at the lacrimal sac region, and if nothing was coming out, lacrimal syringing was done. Swabs were sent for direct smear studies and culture to the Department of Microbiology for bacterial and fungal isolation. Primary cultures were done in 24-48 hours (care being taken not to touch the lids, skin or conjunctiva while taking swabs from the lacrimal sac). In cases of acute lacrimal abscess on chronic dacryocystitis, pus was drained and sent for culture.

Microbiological examination included Gram staining, $\mathrm{KOH}$ (10\%), Ziehl-Neelsen staining and bacterial and fungal culture. Histopathological examination of the lacrimal sac was done in patients who underwent dacryocystectomy.

The lacrimal sac was examined histologically for chronic inflammation, neoplasms and dacryoliths. 


\section{RESULTS}

A total of 50 cases were studied of which $16(32 \%)$ were males and 34 (68\%) were females. Our study shows highest incidence of chronic dacryocystitis among people in the age group of 50-59 yrs. (32\%). The left side was affected in 24 (48\%). Majority of patients were females and most of them were housewives (42\%) followed by labourers (18\%). Patients belonged to economically poorer sections that lack in their cleanliness and scrupulousness in maintaining their eyes clean.

In our study, $50 \%$ of cases showed only epiphora and $40 \%$ showed epiphora with discharge (mucous or mucopurulent or purulent) as their major symptoms. $34 \%$ of patients presented with diminution of vision due to cataract and were incidentally found to be having chronic dacryocystitis when investigating for cataract surgery. $12 \%$ of patients had associated mucocele. 17 cases had rhinological disorder of which deviated nasal septum was the most common (58.8\%). $25 \%$ of cases had chronic conjunctivitis, which may have been the cause or sequelae of chronic dacryocystitis. $60 \%$ of cases had diabetes mellitus.

Out of 50 samples studied, 20 samples were positive for pneumococci as the causative organism that constitutes $40 \%$ of total samples. Next common organism was found to be Staphylococcus (16\%) followed by Klebsiella (12\%), Pseudomonas, E. coli and Diphtheroids. 8 among 50 samples were sterile showing no organisms at all. Out of 13 patients operated for chronic dacryocystitis by sac excision, 10 patients showed enlarged sac with thick wall and soft feel and the remaining showed shrivelled up sac with thin wall. Microscopic examination of the excised sac showed that the chronic catarrhal type was the most common followed by fibrotic sac.

\section{DISCUSSION}

The present study shows highest incidence in $6^{\text {th }}$ decade (32\%). This correlates well with the study conducted by Chaudhry IA ${ }^{3}$ and by Jouko Hartikainen. ${ }^{4}$ In our study, chronic dacryocystitis was found more commonly in females (68\%), which correlated well with Chaudhry IA, and Jouko Hartikainen, Duke-Elder. In our study, there is a relatively high incidence of disease on left side (48\%) as compared to right side $(28 \%)$, which correlates well with studies by P. Shiva Reddy. 6

Majority of the females were housewives (42\%) and some of them belonged to agricultural community. Most of the females were from middle and lower income group working with wood and dried cow dung for cooking, which gives away lot of smoke particles, which settle down in conjunctival sac and enter nasolacrimal duct through tears and block nasolacrimal duct. In the present study, the main presenting feature is epiphora only (50\%) followed by epiphora with other discharge $(40 \%)$, which correlated well with earlier studies by Jouko Hartikainen $(76 \%)^{4}$ and P. Shiva Reddy $(80 \%) .^{5}$

In our study, pneumococcus was the most commonly grown pathogen (40\%). Common nasal commensals (pneumococcus) are implicated to block the nasolacrimal duct and found in the regurgitant material. Non-granulomatous inflammation consistent with dacryocystitis in the most common diagnosis in our study $(100 \%)$, which correlated well with Anderson NG ${ }^{6}$ study (85.1\%) and Maureillo JA Jr.7 study (89\%). Jouko Hartikainen reported gram-positive bacteria being isolated most frequently especially staphylococcus epidermidis. ${ }^{4}$ Umesh Bareja and Ghose isolated gram-positive cocci predominantly Streptococcus pneumoniae. 4

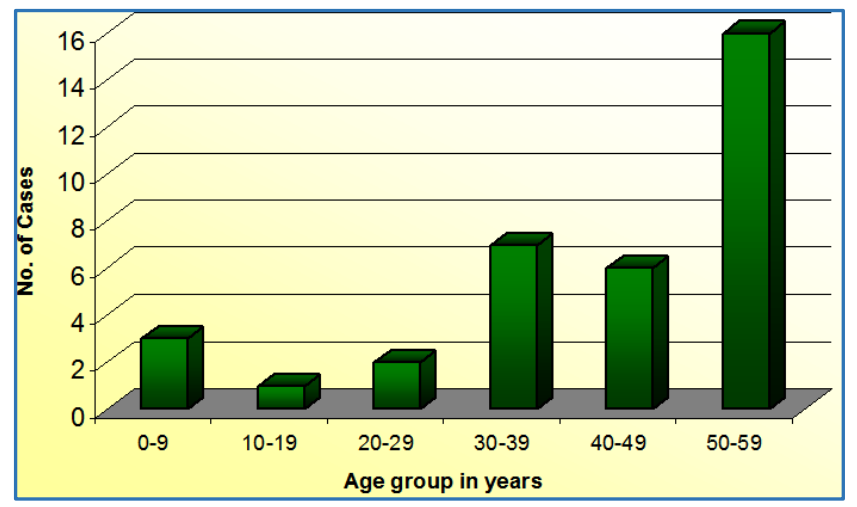

Graph 1: Age-Wise Distribution of Chronic Dacryocystitis

\begin{tabular}{|c|c|c|c|}
\hline Sl. No. & Organisms & No. of Cases & Percentage \\
\hline 1 & Pneumococci & 20 & 40 \\
\hline 2 & Klebsiella & 6 & 12 \\
\hline 3 & E. coli & 2 & 4 \\
\hline 4 & Staphylococcus & 8 & 16 \\
\hline 5 & $\begin{array}{l}\text { Non-fermenting } \\
\text { gram-negative } \\
\text { bacilli }\end{array}$ & 1 & 2 \\
\hline 6 & Pseudomonas & 2 & 4 \\
\hline 7 & $\begin{array}{l}\text { Beta haemolytic } \\
\text { streptococci }\end{array}$ & 1 & 2 \\
\hline 8 & Diphtheroids & 2 & 4 \\
\hline 9 & Sterile & 8 & 16 \\
\hline \multicolumn{2}{|r|}{ Total } & 50 & \\
\hline
\end{tabular}

\section{CONCLUSION}

Every case of dacryocystitis has to be investigated to detect the predisposing and precipitating factor. Detailed examination of a case of dacryocystitis includes a detailed history, clinical examination, microbiological and routine investigations paying attention to rhinological examination to aim at a proper diagnosis with the available facilities.

\section{REFERENCES}

1. Putterman AM. Basic oculoplastic surgery. Chapter 33 in Principles and practices of ophthalmology. Peyman, Sanders, Goldberg. Vol 3. Philadelphia W.B. Saunders 1994.

2. Sihota R, Tandon R. Diseases of the lacrimal apparatus. Parson's diseases of the eye. 19th ed. ButterworthHeinemann 2003:499.

3. Chaudhry IA, Shamsi FA, Al-Rashed W. Bacteriology of chronic dacryocystitis in a tertiary eye care center. Ophthal Plast Reconstr Surg 2005;21(3):207-10.

4. Hartikainen J, Olli-Pekka L, Saari K. Bacteriology of lacrimal duct obstruction in adults. $\mathrm{Br} \mathrm{J}$ Ophthalmol 1997;81(1):37-40.

5. Reddy SP, Reddy BD. Dacryocystitis-a clinicopathological study. J Indian Medical Association 1955;24:413-6.

6. Anderson NG, Wojno TH, Grossniklaus HE. Clinicopathologic findings from lacrimal sac biopsy specimens obtained during dacryocystorhinostomy. Opthal Plast Reconstr Surg 2003;19(3):173-6.

7. Mauriello JA Jr, Palydowycz S, DeLuca J. Clinicopathologic study of lacrimal sac and nasal mucosa in 44 patients with complete acquired nasolacrimal duct obstruction. Ophthal Plast Reconstr Surg 1992;8(1):13-21. 